\title{
Gender-Dependent Reference Range of Serum Calcitonin Levels in Healthy Korean Adults
}

\author{
Eyun Song ${ }^{1}$, Min Ji Jeon², Hye Jin Yoo ${ }^{1}$, Sung Jin Bae ${ }^{3}$, Tae Yong Kim², Won Bae Kim², Young Kee Shong ${ }^{2}$,
} Hong-Kyu Kim ${ }^{3}$, Won Gu Kim²

${ }^{1}$ Division of Endocrinology and Metabolism, Department of Internal Medicine, Korea University College of Medicine; ${ }^{2}$ Division of Endocrinology and Metabolism, Department of Internal Medicine, ${ }^{3}$ Department of Health Screening and Promotion Center, Asan Medical Center, University of Ulsan College of Medicine, Seoul, Korea

Background: Serum calcitonin measurement contains various clinical and methodological aspects. Its reference level is wide and unclear despite sensitive calcitonin kits are available. This study aimed to identify the specific reference range in the healthy Korean adults.

Methods: Subjects were $\geq 20$ years with available calcitonin (measured by a two-site immunoradiometric assay) data by a routine health checkup. Three groups were defined as all eligible subjects (group 1, $n=10,566$ ); subjects without self or family history of thyroid disease (group 2, $n=5,152$ ); and subjects without chronic kidney disease, autoimmune thyroid disease, medication of proton pump inhibitor/H2 blocker/steroid, or other malignancies (group 3, $n=4,638$ ).

Results: This study included 6,341 male and 4,225 female subjects. Males had higher mean calcitonin than females $(2.3 \mathrm{pg} / \mathrm{mL}$ vs. $1.9 \mathrm{pg} / \mathrm{mL}, P<0.001)$ in group 1 . This gender difference remained similar in groups 2 and 3 . Calcitonin according to age or body mass index was not significant in both genders. Higher calcitonin in smoking than nonsmoking men was observed but not in women. Sixty-nine subjects had calcitonin higher than the upper reference limit $(10 \mathrm{pg} / \mathrm{mL})$ and 64 of them had factors associated with hypercalcitoninemia besides medullary thyroid cancer. Our study suggests the reference intervals for men who were non, ex-, current smokers, and women (irrespective of smoking status) as $<5.7,<7.1,<7.9$, and $<3.6 \mathrm{pg} / \mathrm{mL}$, respectively.

Conclusion: Specific calcitonin reference range should be provided considering for sex and smoking status. Taking account for several factors known to induce hypercalcitoninemia can help interpret the gray zone of moderately elevated calcitonin.

Keywords: Calcitonin; Reference values; Sex; Smoking

\section{INTRODUCTION}

Calcitonin is a 32 amino acid polypeptide hormone produced by parafollicular $\mathrm{C}$ cells [1]. The disulfide bridges at the $\mathrm{N}$ - and $\mathrm{C}$ terminals play a functionally essential role in biological activity

Received: 11 December 2020, Revised: 20 January 2021,

Accepted: 28 January 2021

Corresponding author: Won Gu Kim

Division of Endocrinology and Metabolism, Department of Internal Medicine, Asan Medical Center, University of Ulsan College of Medicine, 88 Olympic-ro 43-gil, Songpa-gu, Seoul 05505, Korea

Tel: +82-2-3010-5883, Fax: +82-2-3010-6962, E-mail: wongukim@amc.seoul.kr
[2]. The development of an immunoradiometric assay using two different monoclonal antibodies — each recognizing the N- and C-terminals - allowed more specific and sensitive assays to detect the mature 32 amino acid monomer of calcitonin compared with the radioimmunoassay of the past using polyclonal anti-

\section{Copyright $(\odot 2021$ Korean Endocrine Society}

This is an Open Access article distributed under the terms of the Creative Commons Attribution Non-Commercial License (https://creativecommons.org/ licenses/by-nc/4.0/) which permits unrestricted non-commercial use, distribution, and reproduction in any medium, provided the original work is properly cited. 
bodies which detect not only the mature calcitonin but also other circulating forms, such as precursors or degradation products [2]. This two-site immunoradiometric assay reports calcitonin levels below $10 \mathrm{pg} / \mathrm{mL}$ for the normal healthy population $[3,4]$.

Calcitonin is a key marker for monitoring the disease course in patients with medullary thyroid carcinoma (MTC) $[5,6]$. Despite the improvement of diagnostic techniques, its usefulness in initial screening or diagnosing MTC is an issue of debate $[7,8]$. Although several studies reported that measuring serum calcitonin when evaluating thyroid nodules can detect MTC at an earlier stage and consequently improve the overall survival [9-13], the guidelines do not recommend either for or against its routine measurement in patients with thyroid nodules $[7,14]$. One of the major obstacles to adopting serum calcitonin as a routine test is the lack of an established cutoff value. Calcitonin is not specific for MTC and can be elevated in various conditions such as $\mathrm{C}$ cell hyperplasia, neuroendocrine tumors of nonthyroidal organs (lung, pancreas, and prostate), chronic kidney disease (CKD), autoimmune thyroid disease, hypergastrinemias, presence of heterophilic antibodies, and use of certain drugs (proton pump inhibitors, H2 blockers, or steroid) [15-19]. Moreover, the calcitonin level is affected by age, gender, and cigarette smoking [20-22], which makes determining the precise reference range more difficult. Previous studies defining the reference level of calcitonin are mostly derived from western countries, focused on the young population, or now outdated using the assays of the past. As aforementioned, calcitonin levels under $10 \mathrm{pg} / \mathrm{mL}$ are typically regarded as normal with a twosite immunoradiometric assay. However, this range remains wide, raising the need for redefining its reference level with a lower threshold.

To the best of our knowledge, there are no established normal range for serum calcitonin in Asian adults. Therefore, this study aimed to assess the reference range of serum calcitonin in normal males and females by taking into account the various factors affecting its level by using the data from the routine health checkup in the Republic of Korea.

\section{METHODS}

\section{Study design and subjects}

This cross-sectional study initially included 13,622 subjects aged $\geq 20$ years with available serum calcitonin and thyroid ultrasonography (US) data from a routine health checkup performed at the Health Screening and Promoting Center in Asan Medical Center, Seoul, Korea, from January 2011 to December
2015. Patients with serum calcitonin level $\geq 65 \mathrm{pg} / \mathrm{mL}$ were excluded to minimize the effects of extreme values because this level has been previously examined as a meaningful cutoff value for detecting MTC in Korean subjects [19]. Moreover, subjects with abnormal corrected serum calcium levels $(<8.6$ or $>10.2$ $\mathrm{mg} / \mathrm{dL}$ ) were also excluded because it can affect serum calcitonin levels [23]. Other exclusion criteria were previous history of thyroid cancer and any history of thyroid surgery or radiofrequency ablation for thyroid nodules. Medical records of age, gender, body mass index (BMI), smoking status, kidney function, thyroid autoantibodies, previous medical history, and family history were reviewed. Informed consent was waived, and the Institutional Review Board of Asan Medical Center (No. 20160410) approved the data collection and subsequent analyses.

\section{Laboratory assay}

Serum calcitonin level was measured by immunoradiometric assay-human calcitonin (IRMA-hCT; CisBio International, Codolet, France) with a functional sensitivity, detection limit, and reference upper limit of 4.1, 1.3, and $10 \mathrm{pg} / \mathrm{mL}$ [19]. The intra- and inter-assay coefficients of variation of the serum calcitonin assay was $1.2 \%$ to $6.7 \%$ and $4.3 \%$ to $5.2 \%$, respectively. The same calcitonin assay using IRMA-hCT was used during the whole study period.

Serum free thyroxine levels were measured using a radioimmunoassay kit (Beckman Coulter/IMMUNOTECH, Prague, Czech Republic). Serum thyroid-stimulating hormone (TSH) levels were measured with a TSH-CTK-3 kit (DiaSorin S.p.A., Saluggia, Italy) that had a functional sensitivity and an inter-assay variation coefficient of $0.07 \mathrm{mU} / \mathrm{mL}$ and $20 \%$, respectively. The thyroglobulin antibody levels were determined using a radioimmunoassay (BRAHMS anti-Tgn RIA), and $\geq 60 \mathrm{U} / \mathrm{mL}$ was designated as the minimum threshold denoting positivity. The functional sensitivity of this assay was below $20 \mathrm{U} / \mathrm{mL}$, while the analytical sensitivity from the optimal curve was $5.5 \mathrm{U} / \mathrm{mL}$. Thyroid peroxidase antibody levels were measured using a radioimmunoassay (BRAHMS anti-TPOn RIA), and $\geq 60 \mathrm{U} / \mathrm{mL}$ was again considered positive. The functional sensitivity of this assay was below $30 \mathrm{U} / \mathrm{mL}$, and analytical sensitivity was $5.5 \mathrm{U} / \mathrm{mL}$.

\section{Grouping of subjects}

Subjects were categorized into groups 1, 2, and 3 which included total eligible subjects in group 1; those without thyroid nodules, thyroid dysfunction, family history of thyroid cancer, thyroid hormone, or antithyroid drug administration for any reason in group 2; and, in addition to group 2 criteria, those without CKD 
(defined as estimated glomerular filtration rate $<60 \mathrm{~mL} / \mathrm{min}$ by Modification of Diet in Renal Disease equation), autoimmune thyroid disease (defined as positive thyroid autoantibody with diffuse parenchymal heterogeneity on thyroid US), medication of proton pump inhibitor/H2 blocker/steroid, or other malignancies in group 3, which are all possible factors that can elevate serum calcitonin levels [15-18,20,24,25].

To assess the association between serum calcitonin levels and BMI, the subjects were classified as either underweight (BMI $<18.5 \mathrm{~kg} / \mathrm{m}^{2}$ ), normal (BMI 18.5 to $22.9 \mathrm{~kg} / \mathrm{m}^{2}$ ), overweight (BMI 23 to $24.9 \mathrm{~kg} / \mathrm{m}^{2}$ ), or obese $\left(\mathrm{BMI} \geq 25 \mathrm{~kg} / \mathrm{m}^{2}\right.$ ) based on the Asian-Pacific criteria [26].

\section{Statistical analysis}

The $\mathrm{R}$ version 3.4.0 was used for data analysis ( $\mathrm{R}$ Foundation for Statistical Computing, Vienna, Austria; http://www.R-project.org). Continuous variables were presented as median with interquartile range (IQR) or mean with standard deviation (SD), and analyzed using Mann-Whitney $U$ test or Student's $t$ test, respectively, to compare baseline characteristics between male and female subjects. Categorical variables were presented as numbers with percentages and compared using Pearson's chisquare test. The analysis of variance was used when comparing the mean value of the calcitonin level among the three groups. The differences in $P$ values $<0.05$ were regarded as significant.

\section{RESULTS}

A total of 10,566 subjects were eligible for analyses and were classified as group 1. After excluding subjects with thyroid nod- ules, thyroid dysfunction, family history of thyroid cancer, thyroid hormone, or antithyroid drug administration for any reason, 5,152 subjects were categorized as group 2. Group 3 included 4,638 subjects by further excluding other factors associated with hypercalcitoninemia.

\section{Baseline characteristics}

Table 1 summarizes the baseline clinical characteristics of group 1 subjects. The median age was 55 years (IQR, 49 to 60) with a median BMI of 23.5 (IQR, 21.6 to 25.5). About 50\%, 28.0\%, and $22.5 \%$ of the subjects were non-, ex-, and current smokers, respectively. Thyroid dysfunction was present in $4.6 \%$ of the total subjects, and $1.6 \%$ were taking thyroid hormone or antithyroid drugs. The mean calcitonin level was $2.3 \pm 1.9 \mathrm{pg} / \mathrm{mL}$. When compared according to gender, a higher portion of male subjects were ex- or current smokers $(P<0.001)$ and had more thyroid nodule(s) $(P=0.001)$ than female subjects. However, thyroid dysfunction was more prevalent in females $(P<0.001)$. The mean calcitonin level was higher in males than females $(2.7$ vs. 1.9, $P<0.001)$. The baseline characteristics in groups 1,2 , and 3 are shown in Supplemental Table S1.

\section{Serum calcitonin level according to gender in three groups}

Fig. 1 depicts the serum calcitonin levels in male and female subjects by groups. The mean calcitonin level was higher in males than females in all three groups along with larger SD in males: $2.7 \pm 2.1$ vs. $1.9 \pm 1.5,2.6 \pm 1.9$ vs. $1.9 \pm 1.0$, and $2.6 \pm 1.9$ vs. $1.8 \pm 1.0 \mathrm{pg} / \mathrm{mL}$ in males vs. females in groups $1(P<0.001)$, $2(P<0.001)$, and $3(P<0.001)$, respectively. The mean calcitonin level was similar in three groups for each gender, but the

Table 1. Baseline Characteristics of the Study Subjects

\begin{tabular}{lcccr}
\hline Characteristic & Total $(n=10,566)$ & Male $(n=6,341)$ & Female $(n=4,225)$ & $P$ value \\
\hline Age, yr & $55.0(49.0-60.0)$ & $54.0(48.0-60.0)$ & $55.0(49.0-60.0)$ & 0.025 \\
Body mass index, $\mathrm{kg} / \mathrm{m}^{2}$ & $23.5(21.6-25.5)$ & $24.3(22.5-26.0)$ & $22.3(20.5-24.3)$ & $<0.001$ \\
Smoking & & & & $<0.001$ \\
$\quad$ Nonsmoker & $5,225(49.5)$ & $1,269(20.0)$ & $3,956(93.6)$ & $122(2.9)$ \\
Ex-smoker & $2,962(28.0)$ & $2,840(44.8)$ & $147(3.5)$ & $9.3(9.0-9.5)$ \\
Current smoker & $2,379(22.5)$ & $2,232(35.2)$ & $304(7.2)$ & $121(2.9)$
\end{tabular}

Values are expressed as median (interquartile range), number (\%), or mean \pm standard deviation.

T4, thyroxine. 

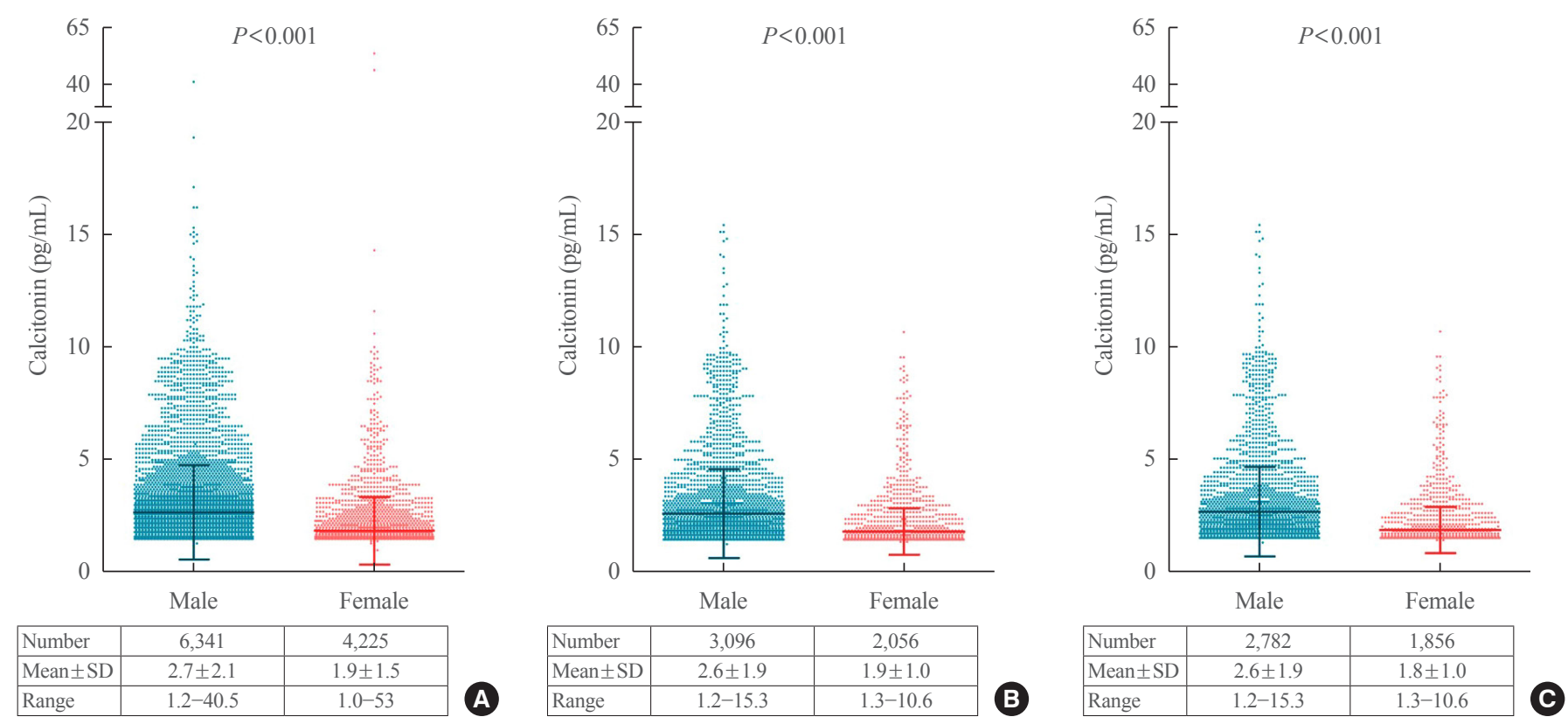

Fig. 1. Serum calcitonin level according to gender in (A) group 1, (B) group 2, and (C) group 3 subjects. SD, standard deviation.
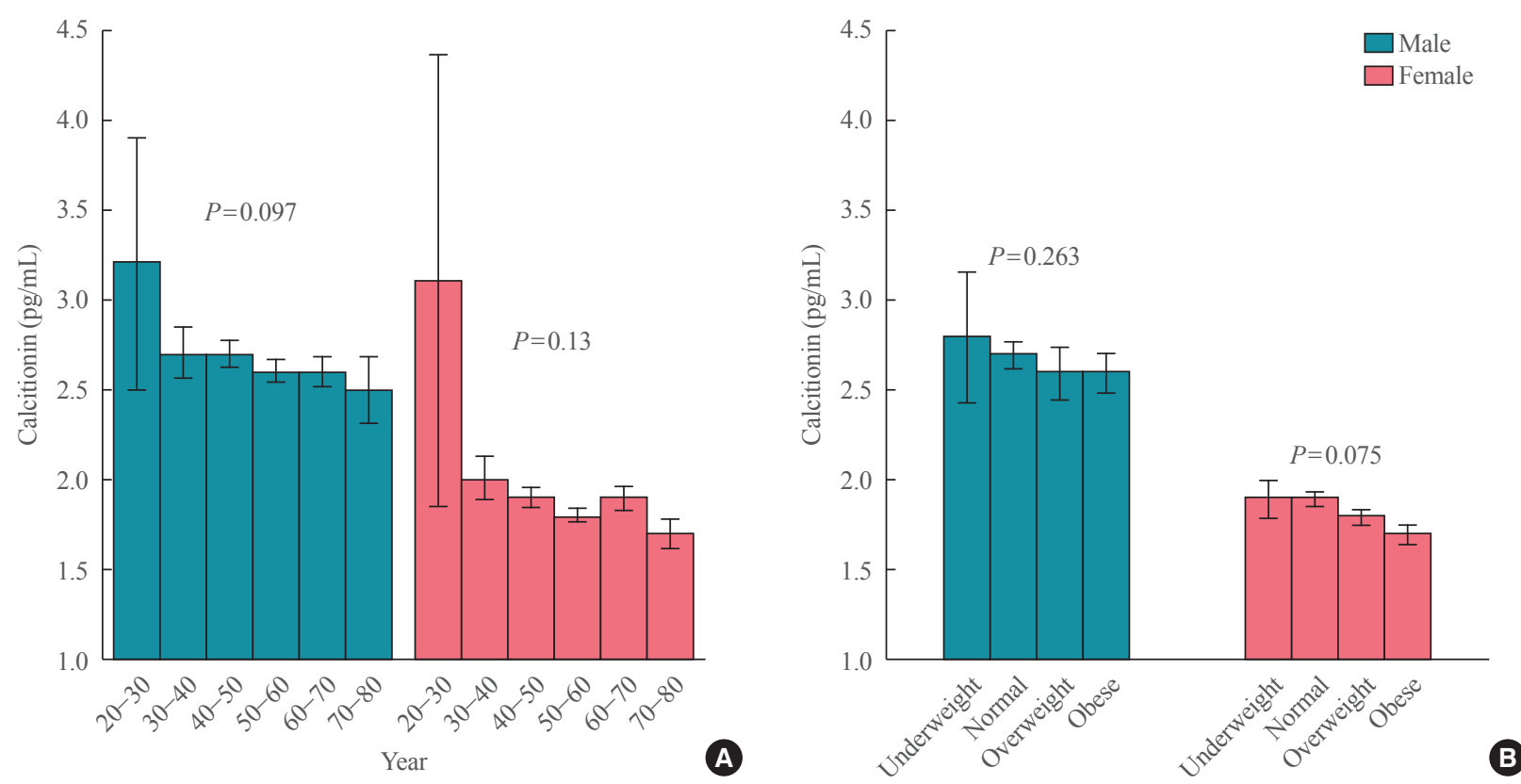

Fig. 2. Serum calcitonin level according to (A) age and (B) body mass index in male and female subjects in group 3.

range was narrower in the subjects in groups 2 and 3 compared with group 1. None of the subjects in groups 2 or 3 had a calcitonin level $>20 \mathrm{pg} / \mathrm{mL}$.

\section{Serum calcitonin level according to age and BMI}

The association between serum calcitonin level and age or BMI was assessed in group 3 (Fig. 2). Fig. 2A shows the calcitonin level according to 10-year age groups. In the older age groups, a trend for lower serum calcitonin levels exists, but the statistical significance was not achieved in both male and female subjects ( $P=0.097$ and $P=0.13$ in males and females, respectively). In addition, Fig. $2 \mathrm{~B}$ shows that no significant relationship between BMI range and calcitonin levels exists in both genders $(P=$ 0.263 and $P=0.075$ in males and females, respectively). 

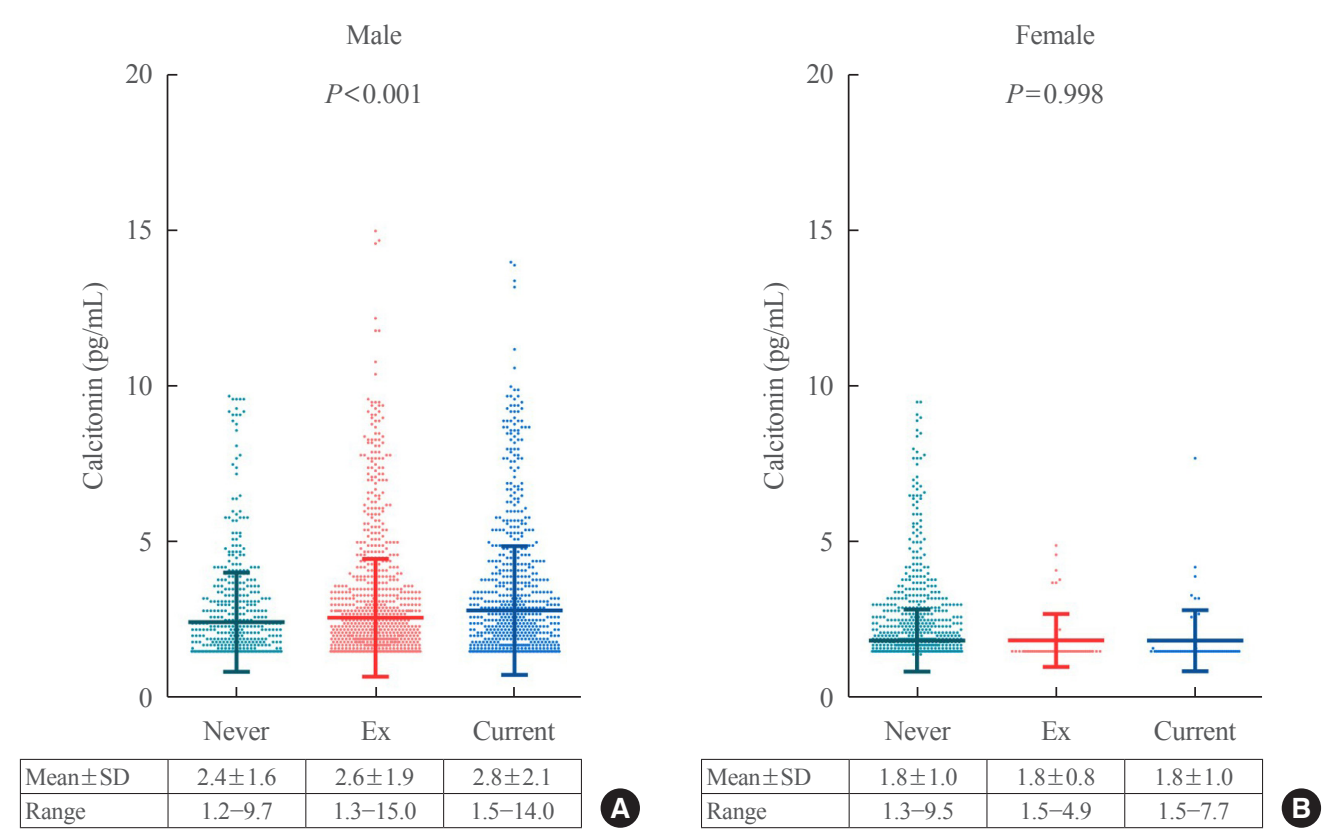

Fig. 3. Association between serum calcitonin level and smoking status in (A) male and (B) female subjects of group 3. SD, standard deviation.
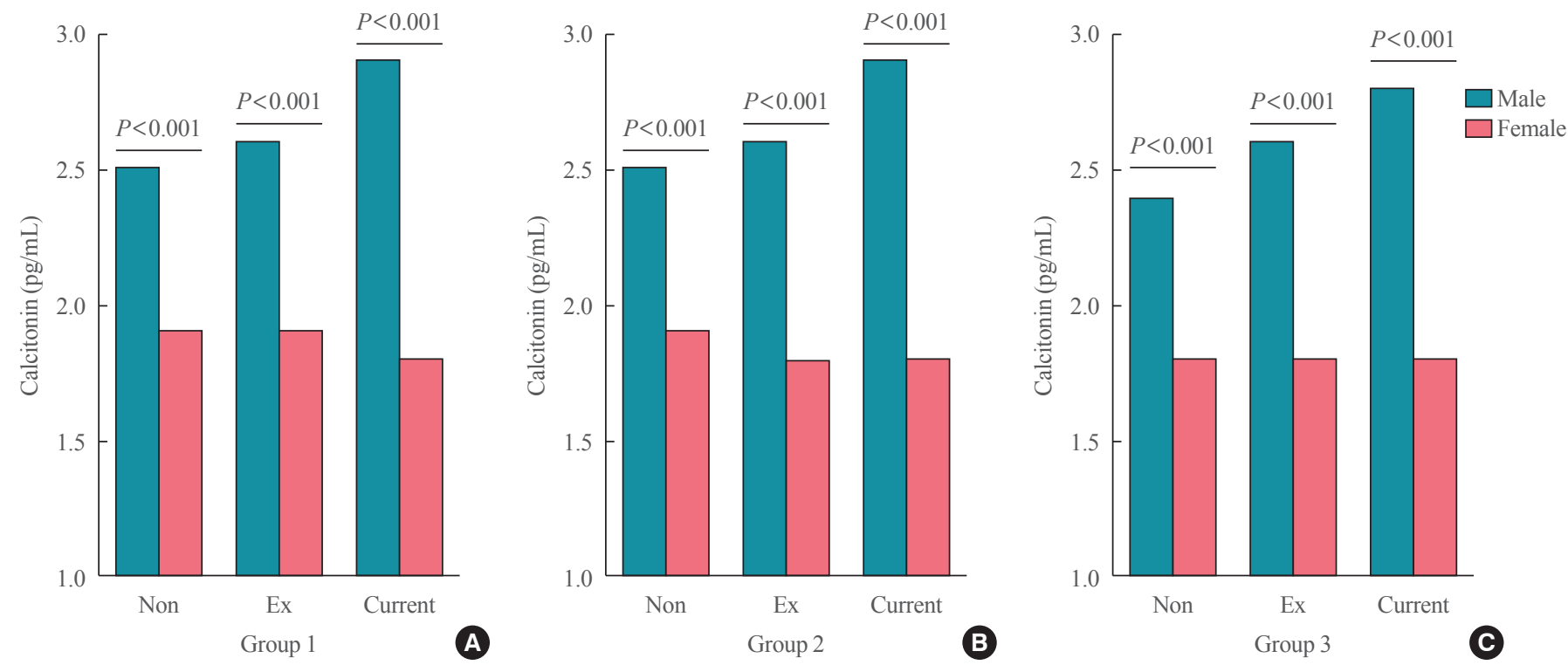

Fig. 4. Comparison of mean serum calcitonin levels according to gender within the same smoking status in (A) group 1, (B) group 2, and (C) group 3 subjects. Error bars show standard error of the mean.

\section{Association between smoking status and serum calcitonin level}

Serum calcitonin levels according to smoking status were assessed in each gender (Fig. 3). In male subjects, the mean calcitonin levels were $2.4 \pm 1.6,2.6 \pm 1.9$, and $2.8 \pm 2.1 \mathrm{pg} / \mathrm{mL}$ in non-, ex-, and current smokers, respectively. Moreover, the difference between the three groups was statistically significant (log-rank, $P<0.001)$. However, no difference in mean calcitonin values exists in female subjects according to their smoking status (1.8 \pm $1.0,1.8 \pm 0.8$, and $1.8 \pm 1.0$ in non-, ex-, and current smokers, respectively; $P=0.998)$.

The difference in mean serum calcitonin level according to gender within the same smoking status category was evaluated (Fig. 4). In group 1, nonsmoker males had significantly higher mean serum calcitonin levels than nonsmoker females $(P<0.001)$ (Fig. 4A). This was similar in the ex- and current smokers in the 


\begin{tabular}{lcc|}
$\begin{array}{l}\text { Table 2. Distribution of Serum Calcitonin Concentrations (95th } \\
\text { Percentile) }\end{array}$ & \\
\hline Variable & Male, pg/mL & Female, pg/mL \\
\hline Group 1 & $1.5-6.5$ & \\
Nonsmoker & $1.5-7.0$ & $1.5-3.5$ \\
Ex-smoker & $1.5-8.1$ & $1.5-4.1$ \\
Smoker & & $1.5-3.3$ \\
Group 2 & $1.5-5.8$ & \\
Nonsmoker & $1.5-7.2$ & $1.5-3.6$ \\
Ex-smoker & $1.5-8.0$ & $1.5-3.8$ \\
Smoker & & $1.5-3.2$ \\
Group 3 & $1.5-5.7$ & \\
Nonsmoker & $1.5-7.1$ & $1.5-3.6$ \\
Ex-smoker & $1.5-7.9$ & $1.5-3.9$ \\
Smoker & & $1.5-3.3$ \\
\hline
\end{tabular}

male and female subjects (all $P<0.001$ ). Identical differencesmales having higher mean serum calcitonin levels than females despite the same smoking status-were observed in groups 2 (Fig. 4B) and 3 (Fig. 4C).

\section{Distribution of serum calcitonin levels}

The distribution of serum calcitonin concentrations as 95th percentile is summarized in Table 2 according to gender and smoking status. In group 1, non-, ex-, and current smoker males had 95th percentile ranges of 1.5 to $6.5,1.5$ to 7.0 , and 1.5 to $8.1 \mathrm{pg} / \mathrm{mL}$, respectively. In the same group, non-, ex-, and current smoker females had 95th percentile ranges of 1.5 to $3.5,1.5$ to 4.1 , and 1.5 to $3.3 \mathrm{pg} / \mathrm{mL}$, respectively. Generally, the 95th percentile range was similar among the three groups within the same gender and smoking status except for the nonsmoking males where the upper 95th percentile value was higher in group $1(6.5 \mathrm{pg} / \mathrm{mL})$ than those in groups $2(5.8 \mathrm{pg} / \mathrm{mL})$ or $3(5.7 \mathrm{pg} / \mathrm{mL})$.

\section{Factors associated with hypercalcitoninemia}

As aforementioned, the upper reference limit of serum calcitonin was $10 \mathrm{pg} / \mathrm{mL}$. Although the majority of the subjects $(99.3 \%$, $n=10,497)$ in group 1 had a calcitonin level of $\leq 10 \mathrm{pg} / \mathrm{mL}, 69$ subjects had a calcitonin level higher than the upper reference limit. The possible factors that can elevate serum calcitonin levels in these 69 subjects are shown in Table 3. Autoimmune thyroid disease (eight subjects), CKD (two subjects), use of proton pump inhibitors (14 subjects), use of $\mathrm{H} 2$ blocker (two subjects), routine steroid administration (two subjects), and other malignancies (three subjects; two lung cancer and one myelodysplas-
Table 3. Possible Factors Associated with Hypercalcitoninemia in Subjects with Serum Calcitonin Level of $>10 \mathrm{pg} / \mathrm{mL}(n=69)$

\begin{tabular}{lc}
\hline Variable & No. (\%) \\
\hline Autoimmune thyroid disease & $8(11.6)$ \\
Chronic kidney disease (stage $\geq 3)$ & $2(2.9)$ \\
Proton pump inhibitors & $14(20.3)$ \\
H2 blockers & $2(2.9)$ \\
Steroid & $2(2.9)$ \\
Other malignancies & $3(4.3)$ \\
Smoking (ex- or current) & $33(47.8)$ \\
Unknown & $5(7.2)$ \\
\hline
\end{tabular}

tic syndrome) were present. Among the 38 remaining subjects without any of these factors, 33 were ex- or current smokers. However, the reason for hypercalcitoninemia is unknown in five subjects.

\section{DISCUSSION}

This large-scale study including 10,566 healthy adults observed significant correlations of serum calcitonin levels with gender in which males had higher serum calcitonin levels than females. Smoking can further elevate calcitonin levels in males, but no such finding was found in females. While subjects aged 20 to 30 years had higher serum calcitonin levels than those aged $\geq$ 30 years, no significant association exists between serum calcitonin levels and age in subjects aged 30 to 80 years in both genders. Moreover, BMI did not affect calcitonin levels either. The results of our study suggest the following reference intervals:

Males: nonsmoker $<5.7 \mathrm{pg} / \mathrm{mL}$; ex-smoker $<7.1 \mathrm{pg} / \mathrm{mL}$; smoker $<7.9 \mathrm{pg} / \mathrm{mL}$

Females: $<3.6 \mathrm{pg} / \mathrm{mL}$ (irrespective of smoking status)

Various factors can increase the concentration of calcitonin as listed in Table 3. These factors should be taken into account when interpreting elevated serum calcitonin levels than the suggested reference levels, especially when $>10 \mathrm{pg} / \mathrm{mL}$.

In this study, males can have higher calcitonin levels than females and this finding is supported by previous studies [20,21]. However, it is unclear why males have normally high calcitonin levels. This gender-dependent pattern cannot be explained by the difference of physique between males and females because BMI did not affect its level, and even under- or normal-weight males exhibited higher calcitonin levels than females in the same BMI range (Fig. 2B). Also, nonsmoking males had significantly higher calcitonin levels compared to nonsmoking fe- 
males (Fig. 4) which leads to the conclusion that smoking in either gender was not the reason for the difference. A previous study of 57 normal autopsy thyroid glands revealed that maximum $\mathrm{C}$ cell surface area was twice as high in men as in women [27]. Moreover, 14 (33\%) adult subjects fulfilled C cell hyperplasia criteria, and 12 out of these 14 adults were men. These suggest that normal adults can have $\mathrm{C}$ cell hyperplasia quite frequently and higher prevalence was observed in males than in females. Some researchers suggested the possible role of androgens in $\mathrm{C}$ cell growth regulation and proposed that testosterone may partially explain the higher serum calcitonin levels in men compared to women [28]. Taken together, it is clear that the reference range of serum calcitonin should be separately provided according to gender.

Smoking - either in the past or currently - evidently elevated calcitonin concentration in males. However, its effect on calcitonin levels in females was not significant. This finding was first reported by d'Herbomez et al. [20]. They reported significantly higher serum calcitonin levels in smoking than nonsmoking men, but no such difference was found in women. A large body of evidence suggests that cigarette smoking alters thyroid function and metabolism [29-31]. However, its specific effect on $\mathrm{C}$ cells is unclear. One study observed nicotine-dependent elevation of calcitonin levels in human serum and urine, and a similar effect was noted in thyroidectomized patients [32]. This phenomenon suggests that the source of calcitonin secreted by smoking is not the thyroid gland but rather the lung, possibly from the pulmonary neuroendocrine cells. The small number of female subjects with smoking habits $(2.9 \%$ and $3.5 \%$ ex- and current smokers, respectively) may have limited this subgroup in reaching statistical significance.

This study classified the subjects from groups 1 to 3 by excluding possible factors associated with hypercalcitoninemia in phases. Groups 1, 2, and 3 included all eligible subjects; those without any self or family history of thyroid disease; and had no evident CKD, medication of proton pump inhibitor/H2 blocker/ steroid, or other malignancies, respectively. The mean serum calcitonin levels were similar in the three groups but the ranges of its level were narrower in groups $2(1.2$ to $15.3 \mathrm{pg} / \mathrm{mL})$ and 3 (1.2 to $15.3 \mathrm{pg} / \mathrm{mL}$ ) compared with group 1 (1.0 to $53.0 \mathrm{pg} / \mathrm{mL}$ ). Although the range still remains wide in group 3, about $97 \%$ of the total subject with serum calcitonin levels higher than the manufacturer's upper reference limit $(10 \mathrm{pg} / \mathrm{mL})$ can be explained by factors other than MTC as shown in Table 3. Increased serum calcitonin release can occur in autoimmune thyroid disease probably due to benign $\mathrm{C}$ cell hyperplasia [33,34].
Nonthyroidal conditions for elevated calcitonin levels include chronic renal failure, various neuroendocrine tumors, hypergastrinemias, presence of heterophilic antibodies, and use of certain drugs (proton pump inhibitors, H2 blockers, or steroid), although each physiological significance and the underlying mechanism remains unclear [15-19,25].

In conclusion, males and smokers have normally higher serum calcitonin levels than their counterparts according to the results of this large sample-sized study of healthy Korean adults. Taking into account the several variables known to induce hypercalcitoninemia can help to interpret moderately elevated serum calcitonin levels and reduce further unnecessary examinations by suspecting MTC in these subjects. Specific calcitonin reference range should be provided considering gender and smoking status, which may ameliorate the role of serum calcitonin in screening for MTCs.

\section{CONFLICTS OF INTEREST}

No potential conflict of interest relevant to this article was reported.

\section{ACKNOWLEDGMENTS}

This study was supported by a grant (No. 2021IL0039) from Asan Institute for Life Sciences, Asan Medical Center, Seoul, Korea.

\section{AUTHOR CONTRIBUTIONS}

Conception or design: E.S., T.Y.K., Y.K.S., H.K.K., W.G.K. Acquisition, analysis, or interpretation of data: E.S., M.J.J., H.J.Y., S.J.B., T.Y.K., W.B.K., H.K.K., W.G.K. Drafting the work or revising: E.S., W.B.K., Y.K.S., W.G.K. Final approval of the manuscript: E.S., M.J.J., H.J.Y., S.J.B., T.Y.K., W.B.K., Y.K.S., H.K.K., W.G.K.

\section{ORCID}

Eyun Song https://orcid.org/0000-0002-6034-0758

Won Gu Kim https://orcid.org/0000-0002-8404-7759

\section{REFERENCES}

1. Pondel M. Calcitonin and calcitonin receptors: bone and beyond. Int J Exp Pathol 2000;81:405-22.

www.e-enm.org 
2. Baloch Z, Carayon P, Conte-Devolx B, Demers LM, FeldtRasmussen U, Henry JF, et al. Laboratory medicine practice guidelines. Laboratory support for the diagnosis and monitoring of thyroid disease. Thyroid 2003;13:3-126.

3. Engelbach M, Gorges R, Forst T, Pfutzner A, Dawood R, Heerdt $\mathrm{S}$, et al. Improved diagnostic methods in the followup of medullary thyroid carcinoma by highly specific calcitonin measurements. J Clin Endocrinol Metab 2000;85:18904.

4. Guilloteau D, Perdrisot R, Calmettes C, Baulieu JL, Lecomte P, Kaphan G, et al. Diagnosis of medullary carcinoma of the thyroid (MCT) by calcitonin assay using monoclonal antibodies: criteria for the pentagastrin stimulation test in hereditary MCT. J Clin Endocrinol Metab 1990;71:1064-7.

5. Wells SA Jr, Asa SL, Dralle H, Elisei R, Evans DB, Gagel $\mathrm{RF}$, et al. Revised American Thyroid Association guidelines for the management of medullary thyroid carcinoma. Thyroid 2015;25:567-610.

6. Ball DW. Medullary thyroid cancer: monitoring and therapy. Endocrinol Metab Clin North Am 2007;36:823-37.

7. Haugen BR, Alexander EK, Bible KC, Doherty GM, Mandel SJ, Nikiforov YE, et al. 2015 American Thyroid Association management guidelines for adult patients with thyroid nodules and differentiated thyroid cancer: the American Thyroid Association guidelines task force on thyroid nodules and differentiated thyroid cancer. Thyroid 2016;26:1-133.

8. Hodak SP, Burman KD. The calcitonin conundrum: is it time for routine measurement of serum calcitonin in patients with thyroid nodules? J Clin Endocrinol Metab 2004;89:511-4.

9. Elisei R, Bottici V, Luchetti F, Di Coscio G, Romei C, Grasso $\mathrm{L}$, et al. Impact of routine measurement of serum calcitonin on the diagnosis and outcome of medullary thyroid cancer: experience in 10,864 patients with nodular thyroid disorders. J Clin Endocrinol Metab 2004;89:163-8.

10. Hahm JR, Lee MS, Min YK, Lee MK, Kim KW, Nam SJ, et al. Routine measurement of serum calcitonin is useful for early detection of medullary thyroid carcinoma in patients with nodular thyroid diseases. Thyroid 2001;11:73-80.

11. Niccoli P, Wion-Barbot N, Caron P, Henry JF, de Micco C, Saint Andre JP, et al. Interest of routine measurement of serum calcitonin: study in a large series of thyroidectomized patients. The French Medullary Study Group. J Clin Endocrinol Metab 1997;82:338-41.

12. Costante G, Meringolo D, Durante C, Bianchi D, Nocera M, Tumino S, et al. Predictive value of serum calcitonin levels for preoperative diagnosis of medullary thyroid carcinoma in a cohort of 5817 consecutive patients with thyroid nodules. J Clin Endocrinol Metab 2007;92:450-5.

13. Chambon G, Alovisetti C, Idoux-Louche C, Reynaud C, Rodier M, Guedj AM, et al. The use of preoperative routine measurement of basal serum thyrocalcitonin in candidates for thyroidectomy due to nodular thyroid disorders: results from 2733 consecutive patients. J Clin Endocrinol Metab 2011;96: 75-81.

14. Yi KH, Lee EK, Kang HC, Koh Y, Kim SW, Kim IJ, et al. 2016 Revised Korean Thyroid Association management guidelines for patients with thyroid nodules and thyroid cancer. Int J Thyroidol 2016;9:59-126.

15. Toledo SP, Lourenco DM Jr, Santos MA, Tavares MR, Toledo RA, Correia-Deur JE. Hypercalcitoninemia is not pathognomonic of medullary thyroid carcinoma. Clinics (Sao Paulo) 2009;64:699-706.

16. Niccoli P, Conte-Devolx B, Lejeune PJ, Carayon P, Henry JF, Roux F, et al. Hypercalcitoninemia in conditions other than medullary cancers of the thyroid. Ann Endocrinol (Paris) $1996 ; 57: 15-21$.

17. Colombo C, Verga U, Mian C, Ferrero S, Perrino M, Vicentini L, et al. Comparison of calcium and pentagastrin tests for the diagnosis and follow-up of medullary thyroid cancer. J Clin Endocrinol Metab 2012;97:905-13.

18. Karanikas G, Moameni A, Poetzi C, Zettinig G, Kaserer K, Bieglmayer C, et al. Frequency and relevance of elevated calcitonin levels in patients with neoplastic and nonneoplastic thyroid disease and in healthy subjects. J Clin Endocrinol Metab 2004;89:515-9.

19. Kwon H, Kim WG, Choi YM, Jang EK, Jeon MJ, Song DE, et al. A cut-off value of basal serum calcitonin for detecting macroscopic medullary thyroid carcinoma. Clin Endocrinol (Oxf) 2015;82:598-603.

20. d'Herbomez M, Caron P, Bauters C, Do Cao C, Schlienger JL, Sapin R, et al. Reference range of serum calcitonin levels in humans: influence of calcitonin assays, sex, age, and cigarette smoking. Eur J Endocrinol 2007;157:749-55.

21. Basuyau JP, Mallet E, Leroy M, Brunelle P. Reference intervals for serum calcitonin in men, women, and children. Clin Chem 2004;50:1828-30.

22. Verga U, Morpurgo PS, Vaghi I, Radetti G, Beck-Peccoz P. Normal range of calcitonin in children measured by a chemiluminescent two-site immunometric assay. Horm Res 2006;66:17-20.

23. Baylin SB, Bailey AL, Hsu TH, Foster GV. Degradation of human calcitonin in human plasmas. Metabolism 1977;26: 
1345-54.

24. Elisei R. Routine serum calcitonin measurement in the evaluation of thyroid nodules. Best Pract Res Clin Endocrinol Metab 2008;22:941-53.

25. Niccoli P, Brunet P, Roubicek C, Roux F, Baudin E, Lejeune $\mathrm{PJ}$, et al. Abnormal calcitonin basal levels and pentagastrin response in patients with chronic renal failure on maintenance hemodialysis. Eur J Endocrinol 1995;132:75-81.

26. World Health Organization. The Asia-Pacific perspective: redefining obesity and its treatment. Sydney: Health Communications Australia; 2000. p. 55.

27. Guyetant S, Rousselet MC, Durigon M, Chappard D, Franc $\mathrm{B}$, Guerin O, et al. Sex-related C cell hyperplasia in the normal human thyroid: a quantitative autopsy study. J Clin Endocrinol Metab 1997;82:42-7.

28. Garcia-Ameijeiras A, De La Torre W, Rodriguez-Espinosa J, Perez-Perez A, De Leiva A. Does testosterone influence the post-stimulatory levels of calcitonin in normal men? Clin Endocrinol (Oxf) 1987;27:545-52.
29. Vestergaard P. Smoking and thyroid disorders: a meta-analysis. Eur J Endocrinol 2002;146:153-61.

30. Schlienger JL, Grunenberger F, Vinzio S, Goichot B. Smoking and the thyroid. Ann Endocrinol (Paris) 2003;64:309-15.

31. Kapoor D, Jones TH. Smoking and hormones in health and endocrine disorders. Eur J Endocrinol 2005;152:491-9.

32. Tabassian AR, Nylen ES, Giron AE, Snider RH, Cassidy MM, Becker KL. Evidence for cigarette smoke-induced calcitonin secretion from lungs of man and hamster. Life Sci 1988;42:2323-9.

33. Vierhapper H, Raber W, Bieglmayer C, Kaserer K, Weinhausl A, Niederle B. Routine measurement of plasma calcitonin in nodular thyroid diseases. J Clin Endocrinol Metab 1997;82:1589-93.

34. Fereira-Valbuena H, Fernandez de Arguello E, Campos G, Ryder E, Avellaneda A. Serum concentration of calcium and calcitonin in hyperthyroidism caused by Graves' disease. Invest Clin 1991;32:109-14. 